\title{
Correlation of Human Epidermal Growth Factor Receptor 2 (HER2), Estrogen Receptor (ER), and Progesterone Receptor (PR) Expression as Predicted by Core Biopsy with the Immunohistochemical Results of Surgical Breast Cancer Specimens
}

\author{
Julian Erggelet ${ }^{a, c}$ Regina Große ${ }^{a}$ Hans-Jürgen Holzhausen ${ }^{b}$ Steffen Hauptmann ${ }^{b}$ \\ Christoph Thomssen ${ }^{\text {a }}$ \\ a Universitätsklinik und Poliklinik für Gynäkologie, \\ b Institut für Pathologie, Martin-Luther-Universität Halle-Wittenberg, Halle/Saale, 'Landesschule Pforta, Bad Kösen, Germany
}

Key Words

Quality assurance · Core biopsy · Immunohistochemistry . Steroid hormone receptors · HER2 overexpression . Breast cancer

\section{Summary}

Background: Representative breast cancer specimens can be obtained by core biopsy. Immunohistochemistry (estrogen receptor: ER, progesterone receptor: PR, and human epidermal growth factor receptor 2: HER2) of core specimens and excised tumors should correlate. Antigen retrieval and tumor heterogeneity may impair immunohistochemical procedures and lead to unreliable results. Patients and Methods: Data was collected from 110 patients with operable invasive breast cancer who were diagnosed by core biopsy between 2001 and 2006, subsequently underwent primary surgery, and had complete immunohistochemical evaluation of biopsy and surgical specimens. ER, PR, and HER2 status were semiquantitatively evaluated. Results: Categorical ER and PR expression correlated in 54\% and $55 \%$, respectively. Clinically relevant ER status (positive versus negative) correlated in $97 \%$ and the PR status in $88 \%$. HER2 overexpression was observed in $18 \%$ of core biopsies and $28 \%$ of surgical specimens with a concordance in $69 \%$. Correlation of categorical HER2 expression $(0,1+, 2+, 3+)$ was present in only $46 \%$. Conclusion: In our patient population, steroid hormone receptor status could be predicted by core biopsy. However, the rather weak concordance of the HER2 status must be further examined. To evaluate whether core biopsies or surgical specimens are better suited to predict the more accurate HER2 status, gene amplification of both specimens should be correlated. Until then, diagnosis of HER2 expression in core biopsy specimens should be interpreted with care.

\section{Schlüsselwörter}

Qualitätssicherung · Stanzbiopsie · Immunhistochemie . Steroidhormonrezeptoren · HER2-Überexpression . Brustkrebs

\section{Zusammenfassung}

Hintergrund: Mittels perkutaner Stanzbiopsie kann man eine repräsentative Gewebeprobe aus Mammakarzinomen gewinnen. Für den Nachweis der Expression des humanen epidermalen Wachstumsfaktorrezeptors-2 (HER2) und des Hormonrezeptorstatus (Östrogen-Rezeptor: ER, Progesteron-Rezeptor: PR) wird eine hohe Korrelation zwischen Stanzbiopsie und Operationspräparat erwartet. Antigenerkennung und Tumorheterogenität können diese Korrelation beeinflussen. Patientinnen und Methoden: Retrospektiv wurden 110 Patientinnen erfasst, die ein stanzbioptisch gesichertes invasives Mammakarzinom mit nachfolgender operativer Therapie und vollständiger immunhistochemischer Auswertung beider Gewebeproben aufwiesen. Ergebnisse: Der Grad der ER-Expression stimmte in 54\% und der der PR-Expression in $55 \%$ überein. Der ER-Status (positiv versus negativ) korrelierte in 97\%, der PR-Status in 88\%. Eine HER2-Überexpression wiesen $18 \%$ der Stanzbiopsiepräparate und $28 \%$ der Operationspräparate auf. Hinsichtlich der klinisch relevanten Befunde zur HER2-Überexpression fand sich in $69 \%$ eine Übereinstimmung. Der HER2-Expressionsgrad (0, 1+, $2+, 3+)$ stimmte in $46 \%$ überein. Schlussfolgerung: In unserer Patientenpopulation war die Korrelation des Hormonrezeptorstatus hochsignifikant. Für die HER2-Expression fanden wir eine signifikante, aber geringere Übereinstimmung. Um zu klären, welches Material den HER2-Status in der Immunhistochemie besser widerspiegelt, muss eine Korrelation mit der Genamplifikation hergestellt werden. Bis dahin sind immunhistochemische Ergebnisse aus der Stanzbiopsie mit Vorsicht zu interpretieren.

\begin{tabular}{ll}
\hline KARGER & @ 2007 S. Karger GmbH, Freiburg \\
Fax +497614520714 & Accessible online at: \\
$\begin{array}{l}\text { E-mail Information@Karger.de } \\
\text { www.karger.com }\end{array}$ & www.karger.com/brc
\end{tabular}

\section{KARGER}

www.karger.com 


\section{Introduction}

In the event of continuous quality-assured medicine, especially in the diagnosis and treatment of breast cancer, even established standard procedures must sometimes be re-evaluated. As the number of breast cancer patients treated at the Center for Breast Disease at the Martin Luther University Hospital in Halle/Germany continues to increase, with approximately $10-15 \%$ of patients clinically eligible for primary systemic therapy, the accurate prediction of cellular tumor characteristics by analysis of diagnostic core biopsy specimens is mandatory.

The correct analysis of human epidermal growth factor receptor 2 (HER2) in core biopsy specimens can optimize primary systemic therapy by allowing the addition of trastuzumab treatment where indicated [1] and avoid unnecessary and costly therapy in other cases. In patients experiencing complete pathological remission, the core biopsy specimen remains the only tissue available for tumor profiling. Correct prediction of steroid hormone receptor status is equally important where neoadjuvant endocrine therapy is an option.

Representative breast cancer specimens may be obtained through quality-assured percutaneous core biopsy. Since major changes in the expression of hormone receptors or HER 2 in the time interval between core biopsy and definitive local therapy in patients not receiving primary systemic therapy is highly unlikely, immunohistochemical properties (estrogen receptor: ER, progesterone receptor: PR, and HER2) of core biopsy specimens and surgically excised tumors should correlate significantly. On the other hand, the antigen retrieval of tissue samples may be altered by fixation and embedding processes. Slamon et al. [2] have reported that a proportion of breast cancers known to have gene amplification and overexpression of HER2 may lose membrane staining after paraffin embedding. The American Society of Clinical Oncology/College of American Pathologists guideline recommendations for human epidermal growth factor receptor 2 testing in breast cancer [3] suggest that fixation time alters protein antigen expression.

We report here on the correlation between immunohistochemical results of ER, PR, and HER2 in core needle biopsy specimens and material obtained from tumor excision.

\section{Patients and Methods}

In this retrospective analysis, data was collected from patients with operable breast cancer who were treated at the Martin Luther University Hospital in Halle/Germany between 2002 and 2006. Patients were only eligible for inclusion if complete immunohistochemical data (ER, PR, and HER2 status) of biopsy specimens as well as excised tumors were available for evaluation. A total of 110 patients between the ages of 32 and 86 years (median 62 years) met these criteria for HER2. Hormone receptor status was complete in 103 cases, ranging in age from 32 to 86 years with a median of 63 years.
ER and PR status was determined by immunohistochemical analysis of formaldehyde-fixed (neutral buffered $4.5 \%$ formaldehyde) and paraffinembedded tissue using the SP1 monoclonal anti-ER and SP2 monoclonal anti-PR antibodies [4, 5] (both LabVision Corp., Fremont CA, USA). The immunoreactive score (IRS) according to Remmele and Stegner [6] defines the intensity of the immunohistochemical reaction of the tumor cells and thereby the content of immunohistochemically detectable receptor proteins. The IRS is the product of the subjective measure of staining intensity (SI): 0 (no staining), 1 (weak staining), 2 (moderate staining), 3 (strong staining) and the objective percentage of positive cells (PP): 0 (no breast cancer cell stained), 1 ( $<10 \%$ of breast cancer cells stained), 2 (10-50\% of breast cancer cells stained), 3 (51-80\% of breast cancer cells stained), 4 ( $>81 \%$ of breast cancer cells stained). Thus, IRS can measure 0 (no expression) to 12 (maximal expression).

Patients with a positive ER and/or PR expression are considered steroid hormone receptor positive and may benefit from the addition of a selective estrogen receptor modulator (tamoxifen) or an aromatase inhibitor to adjuvant systemic therapy. The IRS considered to define a positive expression of ER and PR may vary from institution to institution. In this case, an IRS of 3 and above denoted a positive expression. HER2 status was determined by using the HercepTest ${ }^{\circledR}$ (DAKO Corp., Carpinteria, CA, USA) [7] immunohistochemical assay of formaldehyde-fixed (neutral buffered $4.5 \%$ formaldehyde) and paraffin-embedded tissue. The categorical score is determined by semiquantitative evaluation of cell membrane staining. Possible results of HER 2 expression range from 0 to +3 , whereby 0 and 1 are defined as negative, +2 as equivocal, and +3 as HER2 overexpression [8]. Breast cancer patients with HER2 overexpressing tumors are considered eligible for and may benefit from the addition of trastuzumab (Herceptin ${ }^{\circledR}$ ) to adjuvant or neoadjuvant systemic therapy.

\section{Statistical Methods}

Expression of ER, PR, and HER2 was categorized as described above. Based on these categorical variables, we calculated Spearman rank correlation coefficients ( $r$ ) to quantify the association between expressions based on core biopsies and excised tumors. Values of $r$ vary between +1 and -1 with a positive sign indicating a direct relationship and a negative sign indicating an inverse relationship between the variables. Data were analyzed with SAS for windows, version 9.1., 2002 (Cary, NC, USA) as well as SPSS 12.0 (SPSS Software GmbH, Munich, Germany). Statistically significant correlations were calculated for $\mathrm{p}<0.05$.

\section{Results}

\section{Steroid Hormone Receptor Status}

A comparison of steroid hormone receptor status in biopsy and tumor tissue was possible in 103 cases. Of 103 patients, 76 (74\%) had ER-positive biopsy specimens versus 75 (73\%) ER-positive tumors upon excision, whereas 62 (60\%) showed PR expression in biopsy tissue in comparison with 58 (56\%) in excised tumors. A total of $58(56 \%)$ patients showed an expression of both hormone receptors in biopsy as well as tumor tissue (tables 1, 2).

Categorical expression of the ER in biopsy and tumor tissue correlated in $56(54 \%)$ cases $(r=0.671 ; \mathrm{p}<0.0001)$. The correlation of the PR was given in $57(55 \%)$ cases $(r=0.744$; $\mathrm{p}<0.0001)$. If these values are correlated according to clinically relevant ER and/or PR status, i.e. negative (IRS 0,1,2) or positive (IRS 3, 4, 6, 8, 9, 12), a correlation is seen in $97 \%$ (100) of all cases for ER $(r=0.882 ; \mathrm{p}<0.0001)$ and $88 \%(91)$ of all cases for PR $(r=0.858 ; p<0.0001)$. 
Table 1. Correlation of ER expression in tumor tissue obtained from core biopsies and excised tumors $(\mathrm{r}=0.671 ; \mathrm{p}<0.0001)$
Table 2. Correlation of PR expression in tumor tissue obtained from core biopsies and excised tumors $(\mathrm{r}=0.744 ; \mathrm{p}<0.0001)$

\begin{tabular}{lccccc}
\hline \multirow{2}{*}{$\begin{array}{l}\text { ER expression in } \\
\text { biopsy specimen }\end{array}$} & \multicolumn{2}{l}{ ER expression in excised tumor } & \multirow{2}{*}{ Total } \\
\cline { 2 - 5 } & negative & weak & moderate & strong & \\
\hline Negative & 26 & 1 & 0 & 0 & 27 \\
Weak & 2 & 6 & 6 & 5 & 19 \\
Moderate & 0 & 12 & 13 & 8 & 33 \\
Strong & 0 & 5 & 8 & 11 & 24 \\
\hline Total & 28 & 24 & 27 & 24 & 103 (missing: 7) \\
\hline
\end{tabular}

\begin{tabular}{llllll}
\hline $\begin{array}{l}\text { PR expression in } \\
\text { biopsy specimen }\end{array}$ & \multicolumn{2}{l}{ PR expression in excised tumor } & \multirow{2}{*}{ Total } \\
\cline { 2 - 5 } & negative & weak & moderate & strong & \\
\hline Negative & 37 & 4 & 1 & 0 & 41 \\
Weak & 6 & 9 & 5 & 9 & 29 \\
Moderate & 0 & 6 & 5 & 6 & 17 \\
Strong & 2 & 3 & 4 & 6 & 15 \\
\hline Total & 45 & 22 & 15 & 21 & 103 (missing: 7) \\
\hline
\end{tabular}

Table 3. Correlation of HER 2 expression in tumor tissue obtained from core biopsies and excised tumors, listed according to scoring results $\left(\right.$ DAKO HercepTest $\left.{ }^{\circledR}\right) ;(r=0.587$; $\mathrm{p}<0.0001)$
Table 4. Correlation of HER 2 expression in tumor tissue obtained from core biopsies and excised tumors, categorized according to overexpression (DAKO HercepTest ${ }^{\circledR} 3+$ ) vs. equivocal expression (DAKO HercepTest ${ }^{\circledR} 2+$ ) vs. no overexpression (DAKO HercepTest ${ }^{\circledR} 1+, 0$ ), $(\mathrm{r}=0.580, \mathrm{p}<0.0001)$ as well as overexpression (DAKO HercepTest ${ }^{\circledR} 3+$ ) vs. no overexpression (DAKO HercepTest $\left.{ }^{\circledR} 1+, 0\right)$ excluding equivocal expression (DAKO HercepTest ${ }^{\circledR} 2+$ ), $(\mathrm{r}=0.713, \mathrm{p}<0.0001)$

\begin{tabular}{lrrrrr}
\hline \multirow{2}{*}{$\begin{array}{l}\text { HER2 expression in } \\
\text { biopsy specimen }\end{array}$} & \multicolumn{4}{c}{ HER2 overexpression in excised tumor } & \multirow{2}{*}{ Total } \\
\cline { 2 - 5 } & 0 & $1+$ & $2+$ & $3+$ & \\
\hline 0 & 14 & 6 & 0 & 2 & 22 \\
$1+$ & 20 & 13 & 10 & 7 & 50 \\
$2+$ & 3 & 4 & 6 & 5 & 18 \\
$3+$ & 0 & 1 & 2 & 17 & 20 \\
\hline Total & 37 & 24 & 18 & 31 & 110 \\
\hline
\end{tabular}

\begin{tabular}{lllll}
\hline HER2 overexpression & \multicolumn{2}{l}{ HER2 expression in excised tumor } & \multirow{2}{*}{ Total } \\
\cline { 2 - 4 } in biopsy specimen & negative & equivocal & positive+ & \\
\hline Negative & 53 & 10 & 9 & 72 \\
Equivocal & 7 & 6 & 5 & 18 \\
Positive & 1 & 2 & 31 & 20 \\
\hline Total & 61 & 18 & 110 \\
\hline
\end{tabular}

\section{HER2}

Of 110 patients included in this analysis, 20 (18\%) showed HER2 overexpression in tumor biopsy specimens upon immunohistochemical analysis. In material from surgical specimens 31 (28\%) of the tumors overexpressed HER2. An equivocal expression of HER2 was seen in $18(16 \%)$ cases both of biopsy specimens and excised tumors. Weak HER2 staining was seen in $50(46 \%)$ biopsy specimens, but only in half as many $(24 ; 22 \%)$ excised tumors. The remaining 22 (20\%) biopsy specimens showed no HER2 expression whatsoever, compared to 37 (34\%) excised tumors (table 3).

An agreement between categorical HER2 expression results of both types of tumor specimens can be seen in only 50 $(46 \%)$ of all cases $(r=0.587 ; p<0.0001)$. 
In general, biopsy specimens tended to show a lower overall HER 2 expression. A total of $66 \%$ of all biopsy specimens showed negative or weak HER2 expression, compared to $56 \%$ of excised tumors. On the other end of the scale, almost half of the excised tumors $(44 \%)$ had a DAKO HercepTest ${ }^{\circledR}$ score of $2+$ or $3+$, while only $34 \%$ of biopsy specimens showed an equivocal or definite HER 2 overexpression.

If HER2 expression is compared with regard to clinical significance (overexpression present vs. absent), a much lower concordance between biopsy specimens and excised tumor tissue is seen in the case of HER2 overexpression (55\%) as opposed to lack of overexpression (87\%) of HER2 (equivocal results excluded) (table 4).

Overall, a clinically significant correlation of HER2 status in biopsy specimens compared to excised tumor tissue was observed in $69 \%$ of all investigated cases $(r=0.713$; $p<0.0001)$.

\section{Discussion}

Patients with ER and/or PR expression equal to or greater than IRS 3 are considered steroid hormone receptor positive and may benefit from adjuvant endocrine therapy. ER expression was accurately predicted by immunohistochemical profiling of core biopsy tissue in all but three tumors. All but one ER expressing tumor was accurately identified by immunohistochemical profiling of core biopsy tissue. A total of 2 PR-positive tumors were not identified by this method. In the above cases, a negative expression in core biopsy was followed by a weak expression in excised tumor tissue. Nonetheless, not a single patient with a hormone receptor positive tumor $>$ IRS 4 (for either ER or PR) upon excision would have had endocrine therapy withheld, since these patients showed either ER or PR (but not both) expression in core biopsy tissue. Although clinically significant correlation (ER: 99\% and PR: $88 \%$ ) is statistically highly significant, it is interesting to note that categorical expression of ER (54\%) as well as PR (55\%) is, although also statistically significant, relatively unsatisfactory. Since there is neither a consistent up or down scoring in ER or PR expression of biopsy and tumor tissue, an alteration of antigeneity caused by fixation or embedding processes is unlikely. The most likely explanation for the observed inconsistency in categorical immunohistochemical results is the inhomogeneity of the tumor itself.

Mann et al. [9] comment that tumor heterogeneity and sampling errors in core biopsy could explain some variations in results, however, not those cases with strong staining in the core biopsy but none in the surgical specimen. We did not observe this discrepancy in ER or PR staining results.

The correlation of HER2 expression levels (46\%) was disappointing. Although the immunohistochemical analysis of core biopsy tissue identified $87 \%$ of the HER 2 negative tumors, HER2 overexpressing tumors (3+) were identified in only $55 \%$. When considering the therapeutic consequences of these results, $13 \%$ of patients with HER $2 /$ neu negative tumors upon excision showed moderate to strong HER2/neu expression in core biopsy tissue, while $45 \%$ of patients with HER $2 /$ neu overexpressing tumors did not show overexpression in core biopsy tissue. The significant benefits of trastuzumab therapy $[10,11]$ combined with potential cardiotoxicity in approximately $3 \%$ and the high cost of therapy mandate the highest possible accuracy in HER2 profiling. Ideally, sensitivity and specificity should approach $100 \%$.

In practice, immunohistochemical analysis of core biopsy specimens is a standard in providing the basis for planning primary systemic therapy. Coupled with the immunohistochemical profile of a tumor upon excision in the case of primary operative breast cancer therapy, these data also provide the basis for definitive therapy planning. As far as hormone receptor expression is concerned, the preceding results have shown this practice to be suitable. The overall correlation of clinically significant HER2 expression in this retrospective analysis, while statistically significant at $69 \%$, definitely seems worthy of improvement. In a standard situation, further testing is deemed mandatory only where HER2 expression is equivocal (2+). In these cases, the determination of HER2 gene amplification by fluorescent in situ hybridization (FISH) is recommended. Cahill et al. [12] report that diagnostic core biopsy (DCB) correctly ascribed ER, PR, and HER2 receptor status in most cases $(68 \%, 71 \%$, and $60 \%$ respectively) and accurately identified all tumors with clinically important ER and HER2 expression. Hence, they come to the conclusion that DCB reliably categorizes patients with regard to (neo)adjuvant therapy. Taucher et al. [13] came to similar conclusions. On the other hand, although Mann et al. [9] report on concordance for clinically significant staining of HER2 in $80 \%$, when raw scores were compared, there was concordance in only $42 \%$. Without applying FISH in all of (their) cases, they did not find it possible to determine whether core biopsy or surgical specimen HER2 immunohistochemical assessment is more accurate. Mann et al. [9] report that they do not rely on core biopsy immunohistochemistry for HER2 when making treatment decisions. After analysis of our results, we must come to a similar conclusion. We currently consider only patients with immunohistochemical overexpression of HER2 in both biopsy and tumor tissue to be eligible for trastuzumab therapy without further investigation of gene amplification. Any discrepant immunohistochemical findings which include the results $2+$ or $3+$ in one of both tissue specimens are verified by gene amplification. In order to determine whether the core biopsy specimen or the excised tumor provides the more relevant information pertaining to HER2 status, it is necessary to correlate immunohistochemical and gene amplification results. Only then can we approach the level of accuracy necessary to plan the most suitable primary systemic as well as adjuvant therapy regarding the implementation of trastuzumab in patients with breast cancer. 


\section{References}

1 Hennessy BT, Gonzalez-Angulo AM, Hortobagy GN: Individualization of neoadjuvant therapy for breast cancer according to molecular tumor characteristics. Nat Clin Pract Oncol 2005;2:598-599.

2 Slamon DJ, Godolphin W, Jones LA: Studies of the HER-2/neu proto-oncogene in human breast and ovarian cancer. Science 1989;244:707-712.

3 Wolff AC, Hammond EH, Schwartz JN, Hagerty KL, Allred DC, Cote RJ, Dowsett M, Fitzgibbons PL, Hanna WM, Langer A, McShane LM, Paik S, Pegram MD, Perez EA, Press MF, Rhodes A, Sturgeon C, Taube SE, Tubbs R, Vance GH, van de Vijver M, Wheeler TM, Hayes DF: American Society of Clinical Oncology/College of American Pathologists guideline recommendations for human epidermal growth factor receptor 2 testing in breast cancer. J Clin Oncol 2007;25:118-145.

4 Cano G, Milanezi F, Leitao D, Ricardo S, Brito MJ, Schmitt FC: Estimation of hormone receptor status in fine-needle aspirates and paraffin-embedded sections from breast cancer using the novel rabbit monoclonal antibodies SP1 and SP2. Diagn Cytopathol 2003;29:207-211.
5 Cheang MC, Treaba DO, Speers CH, Olivotto IA, Bajdik CD, Chia SK, Goldstein LC, Gelmon KA, Huntsman D, Gilks CB, Nielsen TO, Gown AM: Immunohistochemical detection using the new rabbit monoclonal antibody SP1 of estrogen receptor in breast cancer is superior to mouse monoclonal antibody 1D5 in predicting survival. J Clin Oncol 2006;24:5637-5644.

6 Remmele W, Stegner HE: Recommendation for uniform definition of an immunoreactive score (IRS) for immunohistochemical estrogen receptor detection (ER-ICA) in breast cancer tissue. Pathologe 1987;8:138-140

7 Elkin EB, Weinstein MC, Winer EP, Kuntz KM, Schnitt SJ, Weeks JC: HER-2 testing and trastuzumab therapy for metastatic breast cancer: a cost-effectiveness analysis. J Clin Oncol 2004;22: 854-863.

8 Lebeau A: HER2 testing in breast cancer: opportunities and challenges. Breast Care 2006;1:69-76.

$\checkmark 9$ Mann GB, Fahey VD, Feleppa F, Buchanan MR: Reliance on hormone receptor assays of surgical specimens may compromise outcome in patients with breast cancer. J Clin Oncol 2005;23:5148-5154.
0 Baselga J, Perez EA, Pienkowski T, Bell R: Adjuvant trastuzumab: a milestone in the treatment of HER-2-positive early breast cancer. Oncologist 2006;11(suppl 1):4-12.

11 Smith I, Procter M, Gelber RD, Guillaume S, Feyereislova A, Dowsett M, Goldhirsch A, Untch M, Mariani G, Baselga J, Kaufmann M, Cameron D, Bell R, Bergh J, Coleman R, Wardley A, Harbeck N, Lopez RI, Mallmann P, Gelmon K, Wilcken N Wist E, Sanchez Rovira P, Piccart-Gebhart MJ: HERA study team. 2-year follow-up of trastuzumab after adjuvant chemotherapy in HER2-positive breast cancer: a randomised controlled trial. Lancet 2007;369:29-36.

12 Cahill RA, Walsh D, Landers RJ, Watson RG: Preoperative profiling of symptomatic breast cancer by diagnostic core biopsy. Ann Surg Oncol 2006;13: 45-51.

13 Taucher S, Rudas M, Mader RM, Gnant M, Dubsky P, Roka S, Bachleitner T, Kandioler D, Steger G, Mittlbock M, Jakesz R: Prognostic markers in breast cancer: the reliability of HER2/neu status in core needle biopsy of 325 patients with primary breast cancer. Wien Klin Wochenschr 2004;116: 26-31. 